\title{
Regimen Used to Treat Merkel Cell
}

\section{Carcinoma}

National Cancer Institute

\section{Source}

National Cancer Institute. Regimen Used to Treat Merkel Cell Carcinoma. NCI Thesaurus.

Code C159443.

Any regimen that can be used for the treatment of Merkel cell carcinoma. 